\title{
Thames Town, an English Cliché
}

The Urban Production and Social Construction of a District Featuring Western-style Architecture in Shanghai

\section{Carine Henriot and Martin Minost}

Translator. Elizabeth Guill

\section{OpenEdition}

\section{Journals}

Electronic version

URL: http://journals.openedition.org/chinaperspectives/7216

ISSN: 1996-4617

\section{Publisher}

Centre d'étude français sur la Chine contemporaine

\section{Printed version}

Date of publication: 1 March 2017

Number of pages: $79-86$

ISSN: 2070-3449

\section{Electronic reference}

Carine Henriot and Martin Minost, «Thames Town, an English Cliché », China Perspectives [Online] 2017/1 | 2017, Online since 01 March 2018, connection on 28 October 2019. URL : http:// journals.openedition.org/chinaperspectives/7216 


\title{
Thames Town, an English Cliché
}

\author{
The Urban Production and Social Construction of a District Featuring Western-style \\ Architecture in Shanghai
}

\author{
CARINE HENRIOT AND MARTIN MINOST
}

\begin{abstract}
This article contributes to the development of a reading grid for the globalisation of urban models and their hybrid forms through an analysis of the urban production and social construction of a district in the suburbs of an emerging Chinese metropolis based on a casestudy of Thames Town, located in the new city of Songjiang, to the south-west of Shanghai. First, this contribution gives an account of the circulation of internationalised urban planning models and practices and the local development of public-private growth coalitions, that is to say, the establishment of new configurations of players promoting "urban marketing" both at the level of the Shanghai Municipality and that of the District of Songiiang. Secondly, this urban creation with its borrowed architectural forms raises questions with regard to both its morphology and its social reception/construction. The "Town on the Thames" presents a meticulous English-style layout that crystallises the tensions encountered in Chinese urban peripheries: gated communities, the staging of Western architectural styles and their appropriation by the inhabitants, the identity enhancement they represent, and over and above this, relationship of the self to others and of others to the self. What do these districts with their Western-style architecture teach us about the way Shanghai, a metropolis that wishes to transmit its own model of Chinese urban planning, thinks, produces, and appropriates the Chinese city?
\end{abstract}

KEYWORDS: urban circulation model, urban production, public-private partnership, urban marketing, social construction, gated community, Shanghai.

C hina's urban production, its urban planning practices, and its urban forms started evolving in the early 2000s. Urban landscapes became more modern, rose upward, spread outward, and juxtaposed heterogeneous urban fabrics. Recently-developed residential districts were joined onto old rural towns and connected to the town centre by a dense network of motorways, or even a light railway network. Certain districts built on the outskirts of the big Chinese cities borrowed from Western architecture. (1) Academic research has approached the creation of these Chinese suburban residential districts with their borrowed architecture either through an analysis of urban forms and their borrowings or through the processes of sociospatial differentiation and the emergence of gated communities. This article stands at the interface of these two approaches, putting Western-style districts back at the heart of the fabric of the Chinese city, from its production to its social construction.

The emergence and spread of districts featuring borrowed foreign architecture in China is related first and foremost to the circulation of urban models, which can be considered from three different angles: the first linked to the force of developments such as the globalisation of markets, imperialism, neo-colonialism, and competition; the second an attempt to understand, at the level of personal relationships between the players, how certain models came about in a specific context; and the third connected to the trajectory taken, to that which circulates between the two, and to the networks of professionals that have fostered these knowledge exchanges. Lieto ${ }^{(2)}$ underlines the links between these approaches through an analysis of their theoretical and practical discourse, focussing on "practices such as they are," and this is what we have chosen to do by placing ourselves at the interface of urban production and social construction. ${ }^{(3)}$
In the case of China, understanding the direction of this circulation constitutes a challenge. Commentators taking a Western-centric view consider these Chinese districts to represent voluntary neo-colonisation, that is to say, the Westernisation of China in accordance with urban and architectural models as well as with neo-liberal forms of consumption issuing from the United States and Europe. Sino-centric commentators, on the other hand, highlight the Chinese system of representation and its integration of the world in order to catch up with technological and cultural advances. Both these critiques focus on the architectural project and its effective realisation without, however, understanding how the space is then perceived and appropriated by its users. ${ }^{(4)}$ Moreover, according to Bosker, shanzhai culture is a widespread and accepted phenomenon. The term refers to the production of counterfeit branded goods reproduced down to the last detail whilst at the same time offering extra features considered to be lacking in the original and intended to meet the specific requirements of a given market.

This article, therefore, goes beyond urban production alone to analyse the social construction of a district of Western-style architecture on the out-

1. Wu Fulong, "Transplanting cityscapes: The use of imagined globalization in housing commodification in Beijing," Area, Vol. 36, No. 3, 2004, pp. 227-234.

2. Laura Lieto, "Cross-border mythologies: The problem with traveling planning ideas," Planning Theory, Vol. 14, No. 2, 2015, pp. 115-129.

3. Setha Low, "Spatializing Culture:The Social Production and Social Construction of Public Space in Costa Rica," American Ethnologist, Vol. 23, No. 4, 1996, pp. 861-879; "The term social construction may then be conveniently reserved for the phenomenological and symbolic experience of space as mediated by social processes such as exchange conflict, and control. Thus the social construction of space is the actual transformation of space - through people's social exchanges, memories, images, and daily use of the material setting - into scenes and actions that convey symbolic meaning"; Setha Low, Spatializing Culture: The Ethnography of Space and Place, New York, Routledge, 2016, XII-263 pp.

4. Bianca Bosker, Original Copies: Architectural Mimicry in Contemporary China, Hong Kong, Hong Kong University Press, University of Hawai'i Press, 2013, XII-164 pp. 
skirts of an emerging Chinese metropolis through the case of Thames Town, situated in the new city of Songjiang, southwest of Shanghai. The "town on the Thames" is characterised by English-style urban markers such as red telephone boxes and traffic lights on poles painted with horizontal black and white stripes. This urban creation with its borrowed architectural forms presents a meticulously planned layout that crystallises the tensions encountered in Chinese suburbs: the gated community, the staging of Western architecture and its appropriation, the identity enhancement it represents, and over and above this, the relationship of the self with others, and of others with the self.

What do these Western-style districts teach us about the way in which Shanghai, a metropolis that wishes to transmit its own model of Chinese urban planning and modernity, thinks, produces, and appropriates the Chinese city?

\section{Western urban references in Shanghai}

The presence of urban objects that imitate, or are inspired by, non-native architectural styles is not without precedent in China. The Emperor had replicas of foreign monuments made for his palace, displaying his overarching power through this miniature world. (5) Foreign concessions were also marked by architecture, road-works, and infrastructure borrowed from England, France, or Germany, ${ }^{\left({ }^{6}\right)}$ whilst mono-industrial satellite towns and the monuments in Tiananmen Square were inspired by the Soviet model. However, the present case is unique in that although the Western-inspired districts are not exclusively reserved for an élite or dictated by a foreign power, they nonetheless make use of Western references. The importance of "being modern" through these borrowings is emphasised mainly in Shanghai, where a cross-bred culture, somewhere between East and West, is emerging: the "Shanghai style" (haipai 海派). (7) Wu Fulong and Marie-Claire Bergère juxtapose the creation of districts of borrowed foreign architecture produced in the concessions and contemporary creations linked to urban development. ${ }^{(8)}$

\section{"One City, Nine Towns": Portraits of globalisation}

At the end of the year 2000, as part of its Tenth Five-Year Plan (20012005), the principal slogan of which was "urbanising the suburbs," the central government published a document promoting the development of small and medium-sized urban units. ${ }^{(9)}$ In response to this, in January 2001, the Municipality of Shanghai delivered its "Proposals for the Development of the Towns of Shanghai," (10) the origin of the "One City, Nine Towns" (yi cheng jiu zhen 一城九镇) ${ }^{(11)}$ pilot project launched in 2001, which planned the development of districts of Western-style architecture on the outskirts of Shanghai, (12) intended to introduce the urban design principals of the New Urbanism. ${ }^{(13)}$

This pilot operation prescribed the development of a "new town" for each suburban district. The municipal and district governments sought, in a coordinated way, to promote the development of secondary centres within the municipality, to improve the quality of the housing offered in the suburbs, and to increase the "anti-magnetic force" (fan cili 反磁力) of the suburban administrative town-centre in relation to the city-centre, thereby drawing people and activities from the centre towards the outskirts and constructing a hierarchised polycentric system. ${ }^{(14)}$ The urban network (chengzhen tixi 城镇体系) envisaged in the "One City, Nine Towns" program was four-tiered: the city-centre (zhongxin cheng 中心城), the new cities (xincheng 新城), the administrative town-centres (zhongxin zhen 中新镇), and the towns (jizhen 集镇). ${ }^{(15)}$ The overall structure was designed to permit the inclusion of rural areas within the urban administrative framework, the modernisation of agriculture, and the "civilisation of peasants" (16) in Shanghai as elsewhere in China.

The municipal authorities invited each suburban district to develop a "pilot town" (shidian zhen 试点镇) on its territory. The ideas behind the master plans drew on Ebenezer Howard's garden city model, advocating a balance between the centre and each garden city, autonomy at garden city level, and the integration of the town into the country. The overall development was to favour public spaces, green spaces, and water as structural elements of the urban landscape with the aim of creating an urban centrality dedicated to soft mobility. ${ }^{(17)}$ The most frequently cited international example used when presenting this project to the developers and political decisionmakers of Shanghai was, moreover, Milton Keynes. ${ }^{(18)}$

In addition to this, each project had to propose an alternative to the nascent property development, which in order to keep costs to a minimum and rationalise production had to reproduce the same building on a large scale, creating a highly homogenous residential landscape within the same

5. Marshal Sahlins, "Les cosmologies du capitalisme. Le 'Système-Monde' vu du Pacifique" (The cosmologies of capitalism: The "world-system" seen from the Pacific), Le Débat,Vol. 1, No. 118, Paris, Gallimard, 2002, pp. 166-187; Bianca Bosker, Original Copies. Architectural Mimicry in Contemporary China, op. cit

6. Marie-Claire Bergère, Histoire de Shanghai (History of Shanghai), Paris, Fayard, 2002, 530 pp.; Françoise Ged, Shanghai, French Institute of Architecture, 2000, 64 p.; Bryna Goodman and David S-G. Goodman (eds), Twentieth Century Colonialism and China: Localities, the Everyday, and the World, New York, Routledge, 2012, 272 pp.

7. Marie-Claire Bergère, Histoire de Shanghai (History of Shanghai), op. cit.

8. Marie-Claire Bergère, "Le développement urbain à Shanghai; un 'remake' ?" (Urban Development in Shanghai: a remake?), Vingtième siècle. Revue d'histoire, 2005, Vol. 1, pp. 45-65; "Shanghai ou 'l'autre Chine'" (Shanghai or "the other China"), 1919-1949, Annales, ESC, 1979, Vol. 34, No. 5, pp. 1039-1068; Wu Fulong, "Transplanting cityscapes: The use of imagined globalization in housing commodification in Beijing," art. cit.

9. National document: Guanyu cujin xiao chengzhen jiankang fazhan de ruogan yijian.

10. Municipal document: Guanyu shanghai shi cujin chengzhen fazhan de shidian yijian.

11. "One City, Nine Towns" corresponds to the official translation of the yi cheng jiu zhen project.

12. Wang Zhijun and Li Zhenyu, "'Yi cheng, jiu zhen', duijiaoqu xinchengzhen de qishi" (Explanations on the new suburban towns of the "One City, Nine Towns" project), Jianzhu xuebao (Architecture Journal), No. 7, 2006, pp. 8-11; Yu Sijia and Liu Zong "Shanghai jiaoqu xincheng de guihua yu sikao" (Planning and Thoughts on the new towns in the Shanghai suburbs), Chengshi guihua xuekan, Vol. 3, No. 181, 2009, pp. 13-19; Marijn Nieuwenhuis, "Tracing the Politics of Space in One City \& Nine Towns," in Harry Den Hartog (ed.), Shanghai New Towns: Searching for Community and Identity in a Sprawling Metropolis, Rotterdam, 010 Publishers, 2010, pp. 291-304; Li Xiangning, "Heterotopias: Themed Spaces in Shanghai and Los Angeles," in Harry Den Hartog (ed.), Shanghai New Towns: Searching for Community and Identity in a Sprawling Metropolis, Rotterdam, 010 Publishers, 2010, pp. 223-238.

13. The "New Urbanism" movement came about in the 1980s in the United States and Europe and proposed a return to the morphological, functional, and social diversity of districts as well as to soft mobility.

14. Yu Sijia and Liu Zong, "Shanghai jiaoqu xincheng de guihua yu sikao," op. cit.

15. Cao Chunxia, "Chengxiang tongchou beijing xia chongqingshi jinjiaoqu xiao chengzhen guihua de tantao; shanghai 'yi cheng jiu zhen' jianshe dui chongqing de qishi" (The context of the planning of small towns integrating the urban and the rural in the inner suburb of Chongqing; a perspective on the construction of the "One City, Nine Towns" of Shanghai), Chengshi fazhan yanjiu (Urban development studies), Vol. 16, No. 2, 2009, p. 59.

16. Zhou Minghao and Xue Qiuli, "'Otherness' strategy: The Origin of the 'One City, Nine Towns' Plan in Shanghai," Guoji chengshi guihua (International Urban Planning), Vol. 23, No. 2, 2008, pp.113117

17. Wang Zhijun and Li Zhenyu, "'Yi cheng, jiu zhen', duijiaoqu xinchengzhen de qishi," art. cit;; Zhou Minghao and Xue Qiuli, "'Otherness' strategy: The Origin of the 'One City, Nine Towns' Plan in Shanghai," art. cit.

18. Milton Keynes is a British new town, begun in 1967 on the outskirts of Buckingham. Its architecture was innovative and promoted the first energy-efficient buildings. Chinese political decisionmakers knew and used this example when referring to an innovative new town. 
plot and significant morphological differences between plots. To compensate for this homogeneity, the 2001 municipal document drew the attention of the local authorities to China's entry into globalisation and the need to improve the form and functioning of Chinese cities by drawing on a variety of architectural styles. ${ }^{(19)}$ To give each suburb a more clearly defined identity, each new town in the "One City, Nine Towns" program displayed a "characteristic style" (tese fengmao 特色风貌), which was often foreign, following the principle "one town, one style" (yi cheng yi mao 一城一貌). ${ }^{(20)}$ These towns are small urban units with easily identifiable road grids that diverge from the orthogonal grid that often structures contemporary Chinese towns. Their morphological diversification also serves to improve the image of the suburbs in the eyes of the populations of Shanghai city-centre. (21)

Ten large villages or new towns, urban in form and with original architecture, (22) were thus built between 2003 and 2006. Songjiang District, Songjiang New City, 30 kilometres south-west of Shanghai People's Square, was the location for "the town on the Thames."

\section{An English cliché}

A morphological study of Thames Town (taiwushe xiaozhen 泰晤士小镇) reveals the originality of this urban composition with its borrowed English style (yingguo fengge 英国风格). The morphological unity and scale of the district differ from the other property operations in the English-style sector of Songjiang. This exercise in urban style is characterised by its rejection of an orthogonal grid, the north-south orientation of the buildings, and the functionalist model that characterises the planning frameworks of contemporary Chinese cities. It is thus related to the New Urbanism movement. (23)

Thames Town, which extends over $0.96 \mathrm{~km}^{2}$ and was home to 2,300 inhabitants in 2014, has at its centre a "historic" urban core, with "English"style architecture. Around the Neo-Gothic Catholic church and its leafy square inspired by Christ Church in Clifton, Bristol, a knot of narrow, pedestrian, cobbled lanes is bordered by small, two-to-four-storey blocks of flats with shops on the ground floor, which tends to recreate a certain level of urban density and indicates the development's vocation of centrality. Around this historic centre, residential quarters - Robin Apartments, Chelsea Garden, Victoria Garden - are composed of small five-storey blocks of flats. A sector of terraced houses is known as Kensington Garden. Lastly, on the outskirts, are five clusters of cottage-style houses encircling the urban centre: Hampton Garden, Rowland Heights, Nottingham Greenland, Leeds Garden, and the most luxurious of the developments, Windsor Island.

Unlike the other operations in the Songjiang English-style sector such as British Manor, Red Villa, Shanghai Class, and Rose Bush, whose buildings are homogenous, attention to detail has been taken to an extreme in Thames Town. The juxtaposition of homes inspired by different historical periods, architectural styles, shapes, and sizes (bow windows), building techniques, and materials (timber frames, red and grey bricks, and rendering) tends to create an impression of eclecticism. Three different eras are suggested in the public spaces of Thames Town: the historic centre round the Neo-Gothic church and Love Square imitate classical Georgian and Victorian style; the northern side of Holiday Square, encircled by buildings in red and grey brick represents the industrial revolution; and lastly, the semi-circular Municipal Square is bordered by contemporary façades, setting the stage and leading the eye towards the new city beyond Lake Huating. The development has been designed to evoke the historic development of an English town. ${ }^{(24)}$

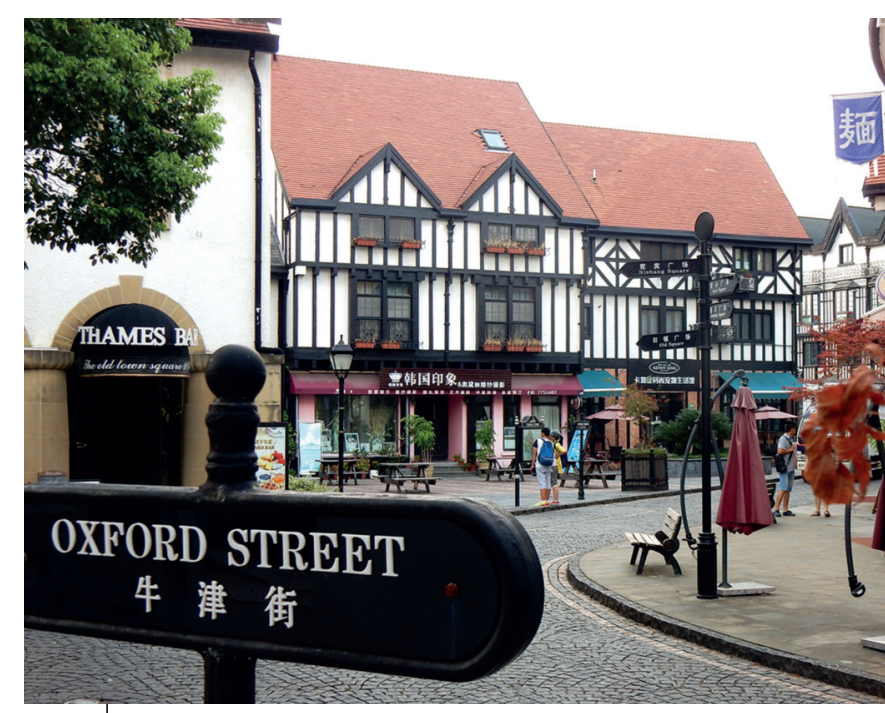

Photo 1 - The "historic" centre of Thames Town in August 2016. () Carine Henriot

Thames Town is also characterised by English urban markers. The names of the streets, for example, are made up of English place-names: Hampton Street, Chelsea Street, Victoria Street, East Street, Thames Rivers Walk, Oxford Street, and Kent Street. The street furniture also evokes London with its red telephone boxes and traffic lights on poles painted with black and white stripes. A sign of "local" adaptation is that the Chinese taste for sculptures of people has been served, and statues of Churchill, Lady Diana, James Bond, and Harry Potter have been placed in the streets. Moreover, all those employed as caretakers sport a red suit reminiscent of those worn by the guards at Buckingham palace. Thames Town has therefore been created, down to the smallest detail, from Chinese markers that recreate an English cliché. Which production model was at the root of this?

\section{A characteristic Chinese urban production?}

The references used in Chinese urban production and its urban planning practices started to evolve in the early 2000 s. Metropolitan governance was now in the hands of the municipal authorities, and the business community entered the urban production chain. ${ }^{(25)}$ The arrival of international operators led to organisational adjustments and favoured decentralised urban management and new forms of planning, dominated by a project rationale in major facilities, services, and urban networks, ${ }^{(26)}$ as well as in the commod-

19. Zhou Minghao and Xue Qiuli, ''Otherness' Strategy: The Origin of the 'One City, Nine Towns' Plan in Shanghai," art. cit.

20. Wang Zhijun and Li Zhenyu, "'Yi cheng, jiu zhen', duijiaoqu xinchengzhen de qishi," art. cit., p. 8.

21. Zhou Minghao and Xue Qiuli, "'Otherness' Strategy: the Origin of the 'One City, Nine Towns' Plan in Shanghai," art. cit.

22. Wang Zhijun and Li Zhenyu, "'Yi cheng, jiu zhen', duijiaoqu xinchengzhen de qishi," art. cit., pp. 8-11.

23. Wang Zhijun and Li Zhenyu, "'Yi cheng, jiu zhen', duijiaoqu xinchengzhen de qishi," art. cit., pp. 811; Zhou Minghao and Xue Qiuli, "'Otherness' Strategy: the Origin of the 'One City, Nine Towns' Plan in Shanghai," art. cit., pp. 113-117.

24. ATKINS (firm), Edina Askem and William Grime (eds.), Atkins: Architecture and Urban Design. Selected and Current Works, Images Publishing, Victoria, 2011, 463 pp.

25. George Lin and Dennis Wei, "China's restless urban landscapes: New challenges for theoretical reconstruction," Environment and Planning A, Vol. 34, No. 9, 2002, pp. 1535-1536.

26. Dominique Lorrain, "Shanghai ou une modernisation publique" (Shanghai or public modernisation), in Dominique Lorrain (ed.), Métropoles XXL en pays émergents (The XXL metropolis in emerging nations), Paris, Les Presses de Science Po, 2011, pp. 53-138. 


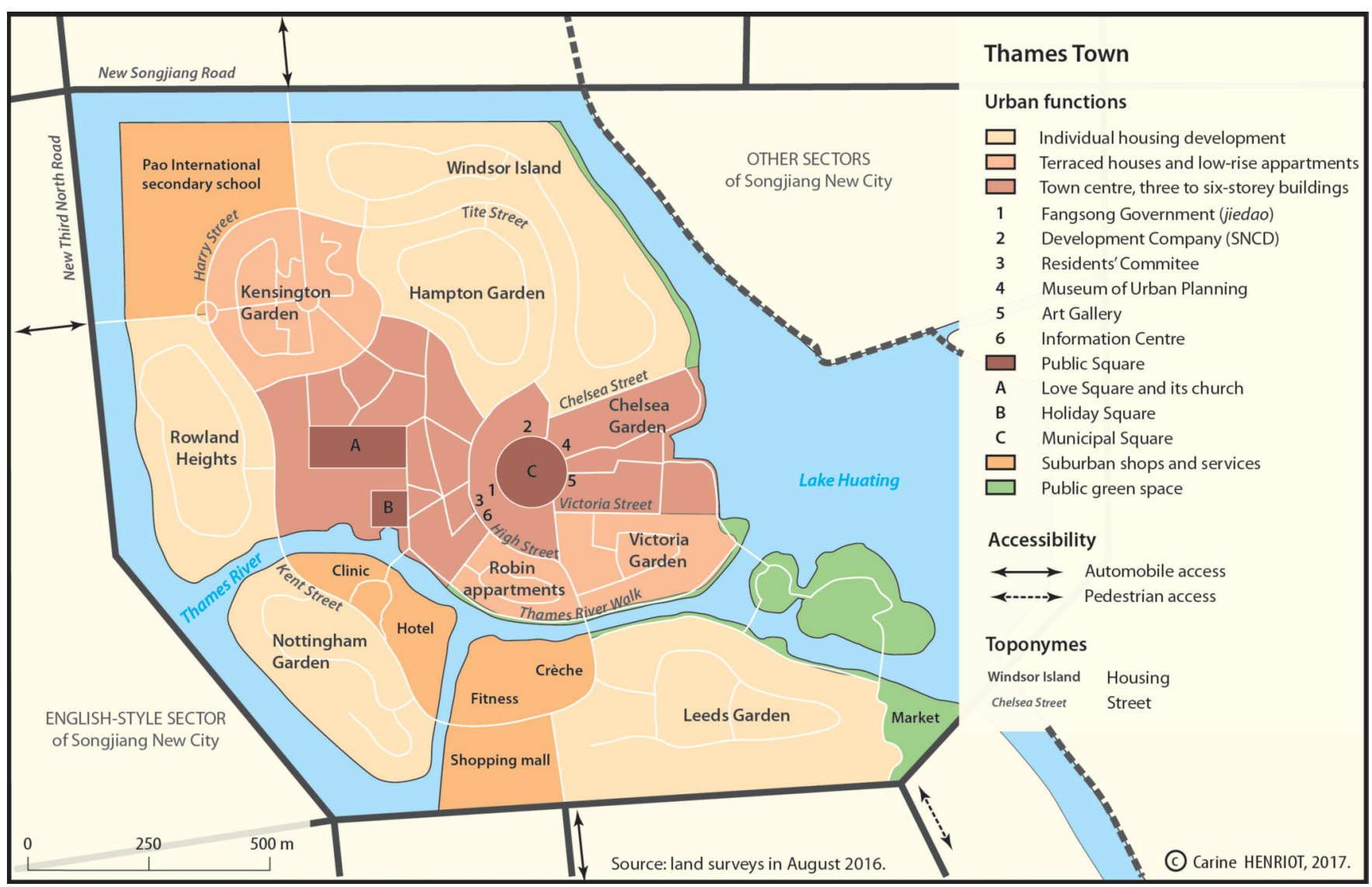

ification of housing. (27) Shanghai therefore positioned itself as an emerging metropolis and at the local level committed all its territories to accelerated globalisation and urbanisation. (28) The municipal authorities strengthened the regulatory role of urban planning ${ }^{(29)}$ and redeployed its metropolitan functions to the new towns situated on the outskirts. ${ }^{(30)}$ Certain areas then borrowed from Western architecture. ${ }^{(31)}$ From which models has the urban production of Thames Town borrowed?

\section{The emergence of public-private partnerships}

Since they were pilot-projects of the Shanghai Municipality, decisions and adjustments concerning the new towns and city involved in the 2001 "One City, Nine Towns" project were made by the Shanghai municipal authorities and then placed under the decision-making and executive responsibility of the districts, which appointed a new city management committee (xincheng guanli weiyuanhui 新城管理委员会) to take charge of the preliminary studies for the project and its subsequent management. The projects introduced into the land and property sectors of the urban fringes the principle of public-private partnerships that raise money, finance, and manage the opening up of new sectors to urbanisation under the control of the district authorities.

In 2001, a competition for the planning of Songjiang New City was organised and judged by members of the local and municipal authorities and specialists in urban planning from Tongji University. Following their deliberations, the British design, engineering, and project management consultancy Atkins was pronounced the winner and was requested to modify its project in accordance with the remarks of the jury and to integrate certain concepts developed by other consultancies. (32) The competition, which proved highly popular with local governments, allowed them to benefit from the latest methods in terms of urban diagnostics, the drawing-up of specifications, and development proposals. (33) In 2001, 2002, and 2003, the urban planner Anthony McKay, senior consultant with Atkins, designed a Master Plan for the development of

27. Valérie Laurans, "Housing and Comfort in Shanghai:The example of Wanli model residential complex," China Perspectives, No. 39, 2002, pp. 36-45; Valérie Laurans, "Chroniques du confort à Shanghai; Nouvelle donne et jeu social du bien-être dans l'habitat de 1996 à 2005" (Chronicles of comfort in Shanghai: New deal and the social game of well-being in the habitat from 1996 to 2005), Doctoral thesis in Geography, Université Paul Cézanne-Aix- Marseille III, 2008, 518 pp.

28. Thierry Sanjuan, Atlas de Shanghai (Atlas of Shanghai), Autrement, 2009, 88 pp.; Kam-Wing Chan, "Fundamentals of China's urbanization and policy," The China Review, Vol. 10, No. 1, 2010, pp. 79.

29. Nicolas Douay, "Shanghai: Urban Planning Styles in Evolution. Emergence of a 'Harmonious Urbanisation'?" China Perspectives, No. 4, 2008, pp. 16-25; Wu Fulong (Ed.), China's Emerging Cities: The making of new urbanism, Routledge, Vol. XVIII, 2008, 306 pp.

30. Carine Henriot, "Villes nouvelles et redéploiement métropolitain à Shanghai. Les nouvelles périphéries urbaines chinoises" (New towns and metropolitan redeployment in Shanghai. The new Chinese suburbs), Doctoral thesis in Geography, Université Paris 1 Panthéon-Sorbonne, 2013, 440 pp.; Liu Yang, "Les villes nouvelles de Shanghai; rôle et fonctions dans la structuration de la métropole et mixité fonctionnelle à linshan" (Shanghai's new towns: role and functions in the structuring of the metropolis and functional diversity in Jinshan), Doctoral thesis in Architecture, Université Paris-Est, 2014, 485 pp.

31. Liu Yang, "Shanghai; villes nouvelles et inspirations étrangères" (Shanghai: new towns and foreign inspiration), in Clément-Noël Douady (ed.), EuroOrient, No. 33-34, 2011, pp. 101-120.

32. Huang Jing, "Tou shi Songjiang xincheng guihua tese yujian she chuang xin" (A viewpoint on the functionality of planning and innovation in the new town of Songjiang ), Ideal space, No. 6, 2005, pp. 42-47.

33. Marie-Perrine Plaçais, architect-urban planner in Studio 6 at the Institute of Architecture and Urbanism of Tongji University, 24 April 2007. 
60 sq. km of new town that encompassed the old satellite town and included a $23 \mathrm{~km}^{2}$ pilot zone with an English-style sector. (34) In August 2001, Shanghai Songjiang New City Development and Construction Company Ltd. (Shanghai Songjiang xincheng jianshe fazhan youxian gongsi 上海松江新城建设发展有限公司), or SNCD, formed from three municipal companies and Songjiang District, was created to develop a sector of $7.36 \mathrm{~km}^{2}$ to the west of the new town. This involved servicing the land and constructing infrastructure, public facilities, part of the university town, Thames Town, and the Guangfulin Archaeological Museum. (35) The New City Development and Construction Company was the leading organisation in the building project; that is to say, the developer delegated by the district and under the responsibility of the New City Committee. ${ }^{\left({ }^{36}\right)}$ The pilot town of Thames Town, ${ }^{\left({ }^{37}\right)}$ future showcase for the new city of Songjiang, was planned, at the request of the local government, over $1 \mathrm{~km}^{2}$ of the English-style sector in 2003. ${ }^{(38)}$ It was the responsibility of the SNCD as principal developer of the new city to develop the English-style Thames Town. For this company, formed from a public-private partnership that bought the land from the district authorities, servicing the land and then selling on the land use rights to developers, or as in the case of Thames Town, the English-style sector and its experimental town, constituted an urban marketing operation (chengshi yingxiao 城市营销) intended to spotlight and promote the new city of Songjiang.

With this intention, between 2003 and 2004, the SNCD carried out major landscape development programs; in particular, it created Lake Huating, situated to the east of the housing developments, and landscaped the banks of the canals. Between 2004 and 2005, in association with the Shanghai Henghe Real Estate Company, it planned and then developed the heart of the area, its shops, and small apartment blocks. Then between 2006 and 2007, it assigned land use rights to five property developers who developed the five groups of houses situated on the outskirts of the district. These were the last clusters of individual houses to be built in the new city before their building was forbidden due to the rarity of available land and the objective of preserving the municipality's arable land.

The plot for which the SNCD acquired land use rights was sold to them by the district authorities for $420,000 \mathrm{yuan} / \mathrm{mu}$, that is to say $630 \mathrm{yuan} / \mathrm{m}^{2}$. After servicing the land, the company sold part of the land rights for the Thames Town sector to four property developers and made 270 million yuan from the resale of the land rights - a profit of between 50 and $60 \%$. The development company did not limit itself to building the infrastructures and public facilities for Thames Town; it was also engaged in property development, earning an extra 200 million yuan thanks to the sale of a group of individual houses. SNCD's net income from this planning and development operation was around 360 million yuan. ${ }^{(39)}$ In 10 years, between August 2001 and August 2011, it made profits of 2.1 billion yuan from all the projects put together, of which 1.28 billion yuan was net profit, earning the district authorities of Songjiang 730 million yuan in taxes, excluding the initial sale of the land use rights. ${ }^{(40)}$

For the district of Songjiang and the New City Development Corporation, Thames Town was a showcase project designed to stimulate the interest of property developers and individuals, and therefore maximise the rise in land values when land use rights are sold. It is therefore an urban production characteristic of the golden age of urban development in China. Is Thames Town characteristic of a Chinese gated community?

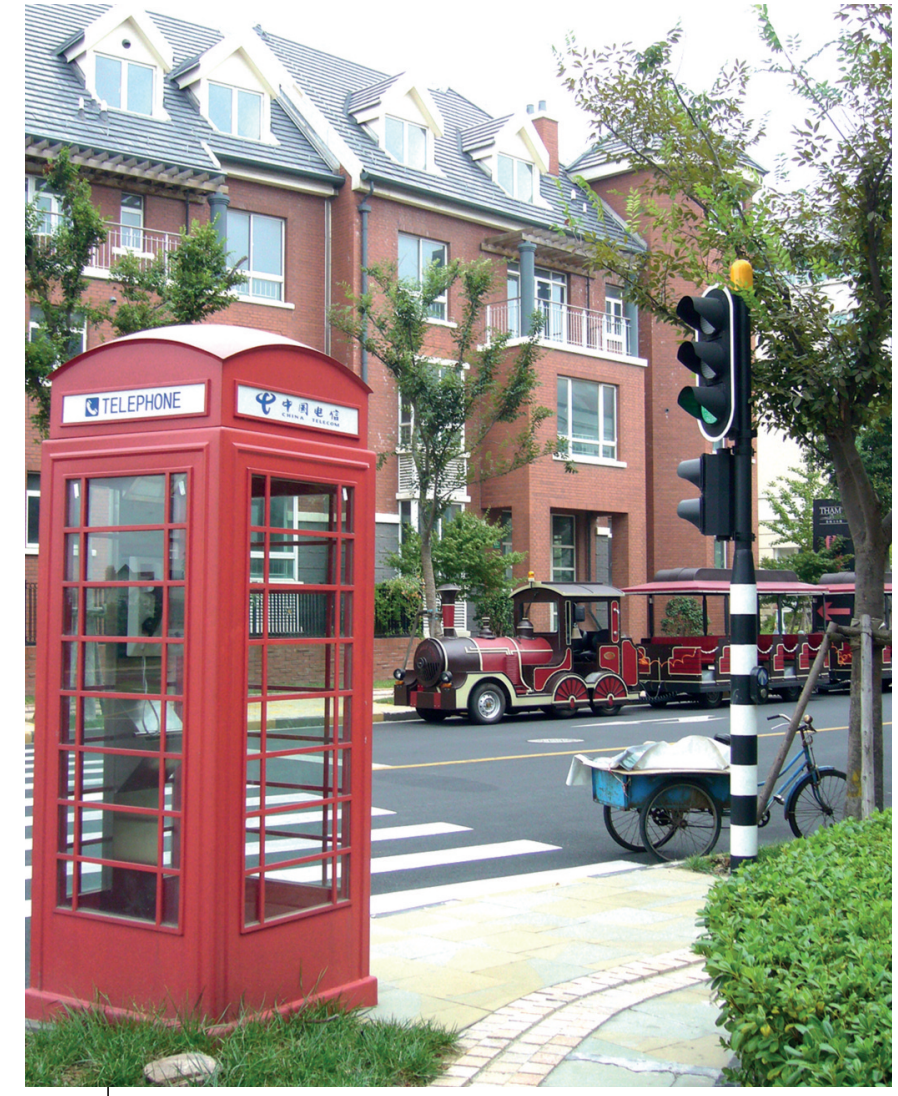

Photo 2 - An English cliché in the suburbs of Shanghai in August 2007. ๑ Carine Henriot

\section{A gated community urban project?}

According to the first feasibility studies for Songjiang New City, ${ }^{(41)}$ a stadium, a theatre, and a conference centre were originally planned for the Thames Town site. Following the organisation of the international competition, the 2002 Songjiang Master Plan diverged from these initial projects to establish Thames Town instead, a sign of the integration by the district authorities of the municipal One City, Nine Towns project into the local New City project that had been under development since the late 1990s.

34. Anthony McKay, British urban planner, senior consultant with Atkins, in charge of Songjiang New Town project; interviewed on 11 March 2011.

35. Ding Xiang, employee in the HR department of the New Town of Songjiang, interviewed on 21 March 2012.

36. Carine Henriot, "Aménager les périphéries urbaines chinoises ville nouvelle et partenariat publicprivé à Shanghai" (Planning the Chinese suburbs: New town and public-private partnership in Shanghai), URBIA. Les cahiers du développement urbain durable, hors-série No. 1, 2013, pp. 207222.

37. Atkins, Master Plan of Thames Town, http://www.atkinsdesign.com/html/projects_masterplanning_thames.htm (consulted on 29 May 2012).

38. Anthony McKay, interviewed on 11 March 2011

39. Shen Jie, "Suburban development in Shanghai:A case in Songjiang," Doctoral thesis in Geography, Cardiff University, School of City and Regional Planning, 2011, XIV-248 pp.; Shen Jie and Wu Fulong, "The development of master planned communities in Chinese suburbs: A case study of Shanghai's Thames Town," Urban Geography, Vol. 33, No. 2, 2012, pp. 183-203.

40. Carine Henriot, "Aménager les périphéries urbaines chinoises; ville nouvelle et partenariat publicprivé à Shanghai" (Planning the Chinese suburbs; New town and public-private partnership in Shanghai), art. cit.

41. Wang Zhenliang (ed.), Zhongguo xincheng guihua dianfan; shanghai songjiang xincheng guihua sheji guoji jingbiao (A planning model for a new town in China: The international competition for the planning of the new town of Songjiang in Shanghai), Shanghai, Tongji daxue chubanshe, 2003, pp. 17. 
Organising an international competition is a means of publicising ambitious planning projects. Debates between Chinese architects and urban planners were reported in Chinese revues as well as on specialist discussion forums. ${ }^{(42)}$ This urban marketing strategy was unquestionably a success if we consider the numerous articles it led to in specialist architecture, urbanism, and urban geography revues, ${ }^{(43)}$ as well as articles written for the general public that considered these urban creations to be perfect images of Chinese modernity. ${ }^{(44)}$

By diversifying the architecture and urban morphology of the new suburbs, the political decision-makers were also seeking to improve the image of the suburb in the eyes of people in the town centre and the Chinese middle classes, who were potential buyers. ${ }^{(45)}$ Songjiang was recognised by the Chinese middle classes as Shanghai's New "English" Town at a time when the Chinese had little opportunity to travel as tourists.

The SNCD decided to differentiate the Thames Town sector by making it morphologically different from the new city. This differentiation was carefully planned and integrated into an urban landscape created for the occasion. The district was separated on three sides from the rest of the new city by a particularly high, thick, green wall, strengthened by drainage canals. As for the eastern side, this looks out onto a vast artificial expanse of water, Lake Huating, a reminder of Songjiang's former place name and which sets the scene for the new city. Moreover, this district only has one entrance accessible to motor vehicles and one entrance for pedestrians. Links to the outside were carefully planned. From the new city, the district cannot be seen, and only the road signs indicate the entrance. The district is completely separate from the rest of the urban fabric of Songjiang.

Since the end of the 1990s, the enclosed and monitored residential sectors that function as adjacent micro-territories have been interpreted as Chinese gated communities. ${ }^{(46)}$ Is Thames Town a gated community? According to Wu Fulong, who has worked on the principle of the enclosure of residential developments ${ }^{(47)}$ and has applied the various gated community models to Chinese cities, ${ }^{(48)}$ there exist three types of closed communities: "lifestyle communities" that depend on one type of lifestyle and where residents get together to share a pastime such as golf, for example; "prestige communities," developments distinguished by social differentiation where the residents group together to elevate their social position; and lastly, "safety communities," developments that have been made safe and that are based on a rising feeling of insecurity, and where the residents live grouped together within a guarded area. Does the Thames Town enclosure provide certain services, does it provide security, or does it represent a superior quality living environment?

In Thames Town, despite having a voluntarily different morphology from the rest of the new city, the district as a whole cannot be considered a closed community. Surveillance cameras are dispersed throughout the district in both the central area and the housing developments. Nonetheless, visitors can walk freely around the town centre and its parks. Access to the residential developments is, on the other hand, restricted to the residents and their guests. Their entrances are monitored and controlled by a barrier, a sentry box, and a guard. However, all these elements of control are present in all residential areas of a certain class and are becoming widespread. Indeed, the enclosure of residential clusters is an integral part of the Chinese urban planning code. However, although an area may be enclosed to comply with the law, this morphological constraint cannot be considered a defining feature of the gated community. To this legal obligation must be added cultural tradition. For the Chinese, alternating wall/door is a way of represent- ing space. So if security is the reason for the gated developments found in the United States, Wu Fulong comes to the conclusion that in China, enclosure and the development of increasingly ostentatious doors are the spatial markers of a community coming together within a residential development to share the same lifestyle. In order to tackle the question of the gated community in China, we must describe the various types of enclosure before raising questions as to their function.

So against a background of opening up to globalisation and tougher competition at all territorial levels, ${ }^{(49)}$ the Chinese new towns and cities, and even more so their Western architecture, correspond just as much to showcase territorial marketing operations ${ }^{(50)}$ characteristic of Chinese urban production as to windows onto the West and its strange and foreign urban forms. ${ }^{(51)}$

\section{The social construction of a district with Western architecture in the suburbs of Shanghai}

Over and above this cliché with its borrowed urban references appropriated by the wedding photography industry and visitors who come to experience Western exoticism, we suggest that Thames Town cannot be reduced to a London theme park intended for visitors to stroll around. In functional terms, its centre is now organised around service activities: residential, commercial, recreational, touristic, cultural, and governmental. Moreover, casual visitors and residents choose Thames Town for its urban environment and

42. Zhou Minghao and Xue Qiuli, "'Otherness' strategy: the Origin of the 'One City, Nine Towns' Plan in Shanghai," art. cit., pp. 113-117.

43. Special press articles on Thames Town: Dong Nannan and Stefanie Ruff, "Managing urban growth in Shanghai. Decentralized urban growth forms a polycentric regional network," Topos, The international review of landscape architecture and urban design, European landscape magazine, No. 58, 2007, pp. 32-35.

44. Non-specialist press articles on Thames Town: Jonathan Watts, "Shanghai surprise... a new town in a ye olde English style," The Guardian, 2004, https://www.theguardian.com/world/2004/jun/02/ arts.china1, 2 June 2004 (consulted on 19 December 2012); Dan Washburn, "Perhaps we should not be surprised Thames Town is full of fakes," Shanghaiist, 2006, http://www.shanghaiist.com/ archives/2006/09/08/how_many_shangh.php, 8 September 2006 (consulted on 23 July 2012); Pierre Julienne, "La Chine, la Tour Eiffel, ses châteaux et ses moulins!" (China, the Eiffel Tower, its castles and mills!), Géo, No. 401, 2012, pp. 46-59.http://www.findarticles.com/p/ articles/mi_qn4158/is_20060814/ai_n16649273

45. Zhou Minghao and Xue Qiuli, "'Otherness' strategy: The Origin of 'One City, Nine Towns' Plan in Shanghai," art. cit., pp. 113-117.

46. Guillaume Giroir, "Le phénomène des gated communities à Pékin ou les nouvelles citées interdites" (The phenomenon of gated communities or the new forbidden cities), in Yves Bocquet (ed.), "Les grandes villes chinoises" (The big Chinese towns), Bulletin de l'Association des géographes français, No. 4, 2002, pp. 423-436; Guillaume Giroir, "The Fontainebleau Villas (Shanghai), a golden ghetto in a Chinese garden," in Wu Fulong (ed.), Globalization and the Chinese City, London-New York, Routledge Curzon, 2006, pp. 208-225.

47. Wu Fulong, "Rediscovering the gate under market transition from work-unit compounds to commodity housing enclaves," in Housing Studies, Vol. 20, No. 2, 2005, pp. 235-254.

48. Wu Fulong, "Gated and packaged suburbia: packaging and branding Chinese suburban residential development," art. cit.

49. Thierry Sanjuan, La Chine et le monde chinois; une géopolitique des territoires (China and the Chinese world: The geopolitics of the territories), Paris, Armand Colin, 2010, 384 pp.

50. Wu Fulong, "Gated and packaged suburbia: Packaging and branding Chinese suburban residential development," Cities, No. 27, 2010, pp. 385-396; Shen Jie and Wu Fulong, "Restless urban landscapes in China: A case study of three projects in Shanghai," Journal of Urban Affairs, Vol. 34, No. 3, 2012, pp. 236.

51. Zhou Minghao and Xue Qiuli, "'Otherness' strategy: The Origin of 'One City, Nine Towns' Plan in Shanghai," art. cit:; Bianca Bosker, Original Copies. Architectural Mimicry in Contemporary China, op. cit.; Martin Minost, "Le Quartier de Thames Town à Songjiang, Shanghai. Questions d'identité et de représentation de l'Occident chez les résidents d'un quartier d'architecture européenne importée," mémoire de master en ethnologie et anthropologie sociale" (The Thames Town District in Songjiang, Shanghai: Questions of identity and representations of the West among residents of a district with borrowed European architecture," Master's thesis in ethnology and social anthropology), EHESS, 2012, 101 pp. 
landscape, contributing, through their practices, to its social construction, (52) as do the developers through their urban production and the image this transmits. How is the Thames Town district represented, perceived, and experienced by its users?

\section{The developer's intention}

Although the SNCD had never sought to produce a theme park in Thames Town, but rather to develop a high quality, small-scale urban centre intended to give priority to shops, services, and people, thus ensuring a functional mix - and in so doing maximising land rents and sales by property developers - it had, over time, to adjust its discourse. The map originally published to promote the district showed the routes taken by the trains taking tourists to see the district with its exotic architecture, ${ }^{(53)}$ whilst from 2007 onwards, the location map posted on boards throughout the district indicated the sights to see (the three squares) and the main services (two cafés and a grocer's store). In 2011, the Thames Town map printed both in a brochure and on the information boards showed photographs of "remarkable monuments." The slogan Wonderful Thames, Wonderful Life (jingcai taiwushi, jingcai shenghuo 精彩泰晤士, 精彩生活) - a local version of the Shanghai Universal Exhibition slogan - highlighted the quality of the environment and linked it, through its iconography and brick red graphics, to English-style architecture. In 2013, the graphics abandoned brick red in favour of green, and the emphasis was placed on shops and services. A new slogan referred to a description of the peaceful living environment: In Thames, Living, Creating, Relaxing (shenghuozhe, chuangyizhe, xiuxianzhe 生活着, 创意着, 休闲着). Most recently, in 2016, the slogan disappeared and was replaced by a list of all the noteworthy sites and the district's shops and services, thus giving way to practices.

\section{Habits of non-residents}

Although in our first visit in 2007 it seemed difficult to imagine permanent life in Thames Town, it has to be said that people have gradually come to live in the town, and the shops and services offered have increased. In 2011, two luxury hotels, cafés, bars, restaurants, and a tea room were established there. The district is also home to the offices of the Development Company and to the Fangsong District authorities' offices, the Urban Planning Museum, the Museum of Industry, and Songjiang Art Gallery, as well as a few private galleries. In September 2011, the church in the centre of Thames Town opened its doors to worshippers, and a priest holds a Catholic mass there every Sunday at $2.00 \mathrm{pm}$. Some of the visitors, inhabitants of Songjiang, and tourists hire bicycles or tandems to tour the town; others come to go rowing, canoeing, or to drive a motor boat on Lake Huating, whilst others stroll around the streets. However, Thames Town cannot be reduced to a theme park or space where leisure pursuits are pursued solely by outside users who have come to discover this English-style setting.

\section{Residential practices: From a pleasant living environment to the construction of a leisure society}

For the inhabitants of Thames Town as well as those in neighbouring residential areas, the district boasts a grocer's store, a sports complex that includes a gym, a swimming-pool, tennis, badminton, and table tennis courts, an international nursery, the Y. K. Pao International Middle and Upper schools, and a clinic. Some shops have opened, whilst others, such as the post office and the dry cleaner's, opened in 2012 and closed in 2015. In 2016, the services offer diversified still further, and there are now two more book shops, two grocers, and another hotel, as well as a yoga studio. Certain buildings, empty for the last five years, have been converted into two shopping malls. In terms of shops and services, therefore, the reach of Thames Town extends beyond use by the inhabitants alone, even if the facilities do not necessarily cover all their needs. Between 2008 and 2014, the resident population more than doubled from 900 residents ${ }^{(54)}$ to more than 2,300. All the inhabitants we were able to meet put forward the same reason for choosing to move to Thames Town: a "nice environment" (huanjing hen hao 环境很好). This was then compared to the environment in Shanghai city centre. For example, in Songjiang and more especially in Thames Town, there are fewer people, the air is fresher and less polluted, there are many green spaces, and it is a good environment in which to bring up children (in the case of the young couples interviewed).

However, this quality of life is never linked to references to the West as such, but rather, though not exclusively, to distinctive practices specific to the construction of a micro-society of leisure, such as playing golf or walking one's dog. According to a survey on residential mobility, ${ }^{(55)}$ moving to Thames Town is a residential mobility strategy, the object of which is above all to benefit from a pleasant living environment without necessarily wishing to recreate social homogeneity within the town. Indeed, the inhabitants of Thames Town that we met were variously from Songjiang and Shanghai, of foreign descent, or foreigners, and belonged to the upper middle and wealthy classes but also to the lower middle classes or even working class categories. The social differentiation observed is not systematically the result of the segmentation of the housing stock into different types, since foreign residents and forms of densification have been observed in operations benefitting from a certain prestige, such as Kensington Garden. In Thames Town, we see a wide social range, a mix that in fact has nothing to do with the social exclusivity of certain closed developments in Shanghai such as the residential developments of Sheshan to the north of the district of Songjiang.

\section{The appropriation of places by Chinese practices}

The inhabitants of Thames Town appropriate the different spaces in the district through practices that echo their Chinese customs. For example, within the residential developments, the inhabitants appropriate shared spaces by spreading their silk coverlets over the benches or dedicated spaces. On the initiative of the Residents' Committee, spaces for gymnastics have been set up within the apartment blocks along with shelters for twowheeled vehicles. Housing has also been appropriated. The balconies are closed off by windows and by a glass roof to make a bay window, and a wash basin has been added. Residents without a balcony have placed a pullout clothes line under their windows. Similarly, certain inhabitants have grown bamboo hedges and planted little Chinese-style or vegetable gardens

52. Setha Low, "Spatializing Culture:The Social Production and Social Construction of Public Space in Costa Rica," op. cit., and Spatializing Culture. The Ethnography of Space and Place, op. cit.

53. Fangsong jiedao zhi (Annals of the Fangsong district), Shanghai cishu chubanshe, Shanghai, 2012, $747 \mathrm{pp}$.

54. Fangsong jiedao zhi, op. cit.

55. Carine Henriot, "Villes nouvelles et redéploiement métropolitain à Shanghai. Les nouvelles périphéries urbaines chinoises" (New towns and metropolitan redeployment in Shanghai: The new Chinese suburbs), art. cit. 
to mark the boundary between their private space and public space. Others have planted loquat trees, a species of fruit that grows in hot regions and symbolises protection for the household.

So like the semi-public spaces within the apartment complexes, houses, and gardens, public spaces are the subject not of hybrid, but of deflected and adapted practices where globalised references and local customs coexist. The inhabitants of Thames Town live in this space but appropriate it whilst preserving their own customs and habits and at the same time socially constructing their Chinese identity.

\section{Conclusion - Thames Town: An English-style cliché characteristic of urban production and social construction in the Shanghai suburbs}

Overall, Thames Town, an exercise in urban planning style, often studied and sometimes decried by Chinese and foreign architects and town planners visiting Tongji University, is characterised by its originality in terms of landscape composition, and this serves as a promotional showcase for the new city of Songjiang. Built between 2003 and 2006, this district, which seemed to us deserted in 2007 during our first visit, is now inhabited and provided with shops and services, creating an impression of life and a second centre within the new city.

Contrary to Hassenpflug's analysis ${ }^{(56)}$ whereby Thames Town cannot be reduced simply to a copy of an English town because its designers have respected the "binary structure" of all Chinese towns, that is to say a closed ghetto of rich inhabitants complete with open facades in the style of a Disney theme park, "the perfect pastiche of a Chinese town," we, on the other hand, think that Thames Town is not a theme park or a group of safe closed communities, and nor is it a lifestyle. Its enclosure complies with the rules of Chinese town-planning, and its implementation remains fairly discrete, since it is limited to a barrier, a sentry box, and a guard. The use of Thames Town's public and semi-public spaces and the services offered there, notably restaurants and cafés, is not reserved for inhabitants of the district but is open to visitors. However, the identity and property enhancement of the residential districts underlines the existence of distinctive practices on the level of both the district and of individual apartment blocks.

This urban creation brings the world and its exoticism to the Chinese, responding to the curiosity of an emerging middle class who ten years ago could not travel abroad, as well as meeting the urban marketing requirements of a residential property market that became highly competitive at the end of the 1990s. The production of a district with borrowed architecture, in the context of a strictly Chinese globalisation, accords a clearly-defined place to foreign countries, their urban forms, and cultural codes. Far from being a mixture, a hybrid, or an example of assimilation, this presentation of different cultural signs is expressed through a juxtaposition of foreign architectures and Chinese new city urban planning that also relied on imported models - that is to say, a juxtaposition of Western and Chinese cultures. However, the inhabitants of these new "exotic" districts live in a pleasant environment whilst preserving their own customs and Chinese identity. And what if Thames Town, a modern Chinese landscape par excellence, was part of the making of an alternative urban modernity specific to the Shanghai metropolis?

\section{Translated by Elizabeth Guill}

Carine Henriot is an Associate Professor in urban and spatial planning at the University of Technology of Compiègne; Member of EA 7284 Avenues; Associate researcher at UMR 8586 Prodig (carine.henriot@utc.fr).

Martin Minost is a PhD candidate in social anthropology and ethnology at the School for Advanced Studies in the Social Sciences (EHESS, Paris); Reasearch Centre on Modern and Contemporary China (CECMC - UMR 8173)

(martin.minost@gmail.com).

Manuscript received on 6 June 2016. Accepted on 8 December 2016. 